Review paper

Received: 6April 2021

Accepted: 14 May 2021

Petra Bučević, univ. bacc. praesc. educ., MA Student

University of Osijek, Faculty of Teacher Education

Department of Social Sciences

petra.bucevic@gmail.com

Ida Somolanji Tokić, PhD, Postdoctoral Researcher

University of Osijek, Faculty of Teacher Education

Department of Social Sciences

isomolanji@foozos.hr; ida.456@gmail.com

\title{
PEDAGOGICAL DOCUMENTATION AND LEGISLATIVE FRAMEWORK OF EARLY CHILDHOOD EDUCATION AND CARE IN CROATIA
}

Summary: The importance and value of pedagogical documentation in the Republic of Croatia is emphasized by the National Curriculum for Early and Preschool Education (OG 01/15). However, in practice there is a different understanding of it, which is a reflection of the theory and practice divide. The divide is perpetuated by other acts and regulations that govern different segments of the educational system. This paper seeks to define pedagogical documentation in the light of the contemporary paradigm of early and preschool education and presents the content of current acts, standards and regulations regarding the definition of pedagogical documentation in relation to the National Curriculum. Although the harmonization of content around the definition of basic concepts does not guarantee their understanding and application in practice, it provides the same starting point needed for systematic quality change. Given that these are basic documents that regulate the work of educational institutions and have direct implications on quality, their compliance with each other and with modern theory is necessary.

Keywords: act, content analysis, convergence, curriculum, reconstruction 


\section{INTRODUCTION}

Pedagogical documentation defined as a process is rarely linked to the legislative framework. Namely, pedagogical documentation understood as a process that primarily leads to a better understanding of the child, his learning and his meaning making, cannot be fully explained (nor is it necessary) through applicable acts, regulations, decisions and even curricula. However, what is needed is the congruence of the entire legislative framework with basic theoretical starting points and a contemporary understanding of pedagogy so that contemporary and at the same time fundamental educational processes can be implemented in a quality and comprehensive way in the educational reality. Contemporary interpretations of pedagogical theory and practice must find their place in the creation of a modern legislative framework, which is achieved by continuous harmonization and modernization of this framework. Consequently, the legislative framework must not be rigidly set or unregulated and vague to the extent that it prevents communication with the system whose basic operation it regulates. Respecting the concept of 'smart' regulation', the legislative framework must be flexible enough to be applicable in different contexts, where it is possible to always act positively and towards the progress of the culture of an individual institution, but also the entire education system, and it must be consistent through a hierarchy of legal regulations. From a pedagogical perspective, Urban et al. (2012) sees this aspect of creating and implementing a competent governance at a policy level as an integral part of a competent system. They state that “A key feature of a 'competent system' is its support for individuals to realize their capability to develop responsible and responsive practices that respond to the needs of children and families in ever-changing societal contexts." (Urban et al., 2012, p. 21). In 2006, when describing quality of a competent system, the OECD (as stated by Urban et al., 2012) proposed a seven interrelated elements framework, with orientation quality and structural quality that refer to the basic legal regulations discussed in this paper. Education concept and practice (Urban et al., 2012) is considered to be the third element

1 The central state portal explains the concept of 'smart' regulation as an approach to legislative activities in such a way that results are achieved with as few obstacles as possible, and as the main goal states the need to drafting and implementation follows the creation of public policy from the beginning of the creation of legislation to the revision of legislation.". https://savjetovanja.gov.hr/postupak-donosenja-propisa-1104/1104. Retrieved March 16, 2021. However, Gunningham and Sinclare (2017) warn that even though smart regulation emphasizes "the importance of designing complementary policy mixes, of harnessing third parties as surrogate regulators and of sequential combinations of public and private enforcement", that the reality is quite different with policymakers paying no attention to this concept. Very openly, the authors claim that "Overall, what passes for smart regulation in policy circles is more akin to a regulatory stew from which policymakers have selected particularly juicy morsels that appeal to the political rhetoric of their masters, largely irrespective of their likely effectiveness or efficiency." (Gunningham \& Sinclare, 2017, p. 144). 
referring usually to the national curriculum framework. Gaining insight into the basic legal regulations governing the system of early and preschool education in the Republic of Croatia revealed a deviation primarily in their recentness and in their content and basic starting points. Guided by basic legal literacy, it can be relatively easily assumed that a newer act or regulation invalidates the older one that contradicts the content of the newer one. However, educational concepts and practice cannot be reduced to legal interpretations through articles and paragraphs, and it is sometimes demanding to distinguish basic pedagogical values and principles used as a starting point in the creation of a legal text which is often read very narrowly. Therefore, it is not always easy for practitioners as well as scholars to discern in which segments there is a substantive discrepancy between the legislative framework and contemporary pedagogical theory and practice, and which act needs to be revised in order to achieve basic harmonization.

This paper aims to present the content of several legal regulations that directly regulate the practice of the system of early and preschool education and to put them in relation to contemporary theory in terms of determining the pedagogical documentation. Pedagogical documentation is considered to be one of the main tools of a reflexive practitioner (Slunjski, 2020) which consequently affect the co-construction of the early and preschool curriculum and overall educational process. More importantly, pedagogical documentation has the potential to develop and nurture a discourse of multiplicity and uncertainty (Dahlberg et alt., 1999) and meaning-making in contrast to ever-present discourse of normalization and datafication (Robert-Holmes, 2014) of children and schoolification of childhood. Such diametrically opposed discourses imbedded in pedagogical documentation on the one side and schoolification on the other side, are topics of research for number of years now (Krechevsky et alt., 2013; Moss, 2013; Slunjski, 2020). Schoolification could be explained as a narrow, uniform and fragmented process of readying children for more formal ways of schooling usually associated with compulsory education (Somolanji Tokić \& Borovac, 2020). It is caused and perpetuated further by a distinct image of a child, of his or her family, and of the school system. As Vandenbroeck confirms, "This image of the child (that needs to learn as soon as possible); of the family (as responsible and accountable towards society); and of the school system (as the best place to learn) leads to a specific image of early childhood education, marked by schoolification (Garnier, 2011; Moss, 2013), marked by an increasing focus on early learning and the subordination of the body." (Vandenbroeck, 2020, p. 31). Moss explained schoolification by saying that "it applies a reductionist, fragmented and narrow approach, which is more about taming, controlling and predicting than creating learning based on movement, experimentation and meaning-making" (Moss, 2012, p. 360). Pedagogical documentation allows maneuvering away from schoolification or 
from, as Krechevsky et alt. (2013) asserts, the demands of standardized testing and normalization of children through check lists and summative assessments, toward a more respecting and engaging process of making learning visible and appreciating multiple perspectives.

For the purposes of this paper authors will present the content of the Act on Preschool Education (2019) ${ }^{2}$, the State Pedagogical Standard of Preschool Education $(2008)^{3}$ and the Ordinance of the content and forms of pedagogical documentation and records on children in kindergartens $(2001)^{4}$ in relation to the National Curriculum for Early and Preschool Education $(2015)^{5}$ and modern pedagogical theory. In the light of the announced public debate on the Draft Proposal of the Act on Amendments to the Act on Preschool Education ${ }^{6}$ from September 2019, which from the perspective of preschool teachers of the early and preschool education system came out to the public extremely non-transparently and in many segments of questionable content, it seems justified to systematically initiate an interdisciplinary debate that would better meet the basic requirements of both contemporary pedagogical theory and practice and the legislative framework.

\section{PEDAGOGICAL DOCUMENTATION}

When defining modern pedagogical documentation, it is useful to start from the National Curriculum (2015) and pedagogical documentation as a "systematic collection of documentation (ethnographic records), which allows observation and better understanding of the child's actions, and thus providing better support for his development. It contributes to creating a culture of inclusion and dialogue between all participants in the kindergarten. (...) Documentation is in itself a research process that develops in parallel with the development of factors that undertake documentation, so its purposes and forms are stated only in outline" (National Curriculum, 2015, p. 45). However, as stated by Moos \& Dahlberg (2008), the definition of pedagogical documentation is always

2 Act on Preschool Education, Official Gazette, no. 10/97, 107/07, 94/13, 98/19 (hereinafter the Act)

3 State Pedagogical Standard for Preschool Education, Official Gazette, no. 63/08 (hereinafter referred to as the State Pedagogical Standard)

4 Ordinance of the content and forms of pedagogical documentation and records on children in kindergartens, Official Gazette, no. 83/01 (hereinafter the Ordinance)

5 National Curriculum for Early and Preschool Education, Official Gazette, no. 5/15 (hereinafter referred to as the National Curriculum)

6 Ministry of Science and Education, Draft Proposal of the Act on Amendments to the Act on Preschool Education, 2019 https://mzo.gov.hr/UserDocsImages/dokumenti/ PristupInformacijama/Zakoni\%20u\%20proceduri/Zakon\%20o\%20izmjenama\%20i $\quad \%$ 20dopunama\% 20Zakona\% 20o\% 20pred\% C5\% A1kolskom\% 20odgoju\% 20i\% 20obrazovanju.pdf? Fbclid = IwAR0Kou1JOBOu_0LV5gh7gi6LOmsNo3YpLfX4HHMM13pD_ VY8WLrRYkn_3QA. Retrieved March 16, 2021. 
accompanied with a certain risk of its narrowed, technical understanding. The existence of a policy document drafted by government or international organizations Moss and Dahlberg (2008) interpret as a phenomenon that often offers a predictable pattern but does not provide a critical approach to practice as various critical reflections and reflections does. They state that "These documents not only make boring and repetitive reading, they stifle democracy. Political and ethical choices are replaced by the search for technical specifications" (Moss \& Dahlberg, 2008, p. 9). In this sense, the existence of an open, developmental curriculum, as presented by the National Curriculum (2015) in the Republic of Croatia, represents a progressive turn in the current practice of setting predictable patterns (and thus normatively predetermined outcomes) thus eliminating the 'technicalization' of theory in practice. It requires critical thinking and reflection to bring the curriculum to life. However, although the National Curriculum (2015) is an open curriculum and its content communicated at the national level ensures a high level of autonomy over normatively determined educational outcomes in other education systems, it is nevertheless a document prescribed by education policy and it is presented in practice as such. As Moss and Dahlberg (2008) warn, it is also at risk of narrowing its content to predictable patterns and technical specifications. It is often its openness, flexibility and the need for critical thinking and reflection an issue in practice. Wood and Hedges (2016) address this problem by stating that there are two opposites and that "working with either overly or loosely defined structures towards overly or loosely defined goals is equally problematic." (Wood \& Hedges, 2016, p. 396). If the practitioner perceives openness and flexibility as uncertainty, then he or she often strives to interpret the definition precisely through the creation of predetermined frameworks, instructions, or technical specifications. It is necessary, therefore, for a comprehensive and deep understanding of the National Curriculum (2015) and pedagogical documentation, although defined very broadly in the National Curriculum (2015), to continuously use contemporary theory on which the document itself relies.

The need for strict methodical instruction (predetermination) of the system of early and preschool education can be redirected towards the need for understanding of the process of the system of early and preschool education only by empowering all participants in the system to understand that process, and this is not possible by reading only one source of knowledge.

Various authors such as Katz (1998), Rinaldi (2006), Rintakorpi (2016) and Slunjski (2020) argue that pedagogical documentation is not a final report or a collection of documents that help memory and assessment, but a comprehensive process that helps educational agency and has the power to change the quality of communication and interaction. According to Lenz Taguchi (2010), pedagogical documentation is not a presentation of practice as it is at the time of documentation, but pedagogical documentation is what it actively does in 
pedagogical practice, at the place where it is produced. Slunjski (2020) defines pedagogical documentation as "activities and efforts aimed at establishing not only existing knowledge and understanding of children, but also studying and understanding the way children think (how they come to conclusions, i.e. which problem-solving strategies they use) in order for their learning could be more effectively supported. These are various forms of indirect support for children's activities and learning that cannot be subsumed under a universal and generally applicable methodological "recipe" (Slunjski, 2020, p. 1). Vujičić (2017) states that " $(\ldots)$ documentation does not seek answers, but creates questions by leading him to think and reflect about what to do next, without giving him final answers." (Vujičić, 2017, p. 23). Likewise, Oliveria-Formosinho \& de Sousa (2019) point out that pedagogical documentation is not a chronological record of didactic sequence sequences, but a multidimensional narrative that speaks of the whole child and its development, of the child's learning as a multidimensional, holistic and deeply contextualized process. The same authors state that pedagogical documentation cannot be learned to 'do' without understanding the process being documented, and that it is necessary to bring oneself into a state of ethical stance of suspension ${ }^{7}$ or a state in which the preschool teachers consciously give themselves enough time and space to pause, to notice, to raise awareness, and document. Similarly, Carr and Lee (2019) state that they start by observing, listening, and using time as a resource, not a schedule. The purpose of such a state or understanding of the process is not the administrative procedure of recording pedagogical practice, but, as Sharmahd and Peeters (2019) and Slunjski (2020) point out, giving value, authenticity and meaning to the child's daily life and experience, so-called ordinary moments (Forman et al., 2001), or the details of everyday life (Sharmahd \& Peeters, 2019). Pedagogical documentation thus goes beyond the material and represents the revival of a culture of democracy - "collectivity, partnership and participation as hallmarks of decision-making" (Mitchell, 2020, p. 199). From the latter, it is assumed that pedagogical documentation is a process that nurtures the constant appreciation of diversity through dialogue and co-construction. The realization of this process in practice, point out Sharmahd and Peeters (2019), and support Slunjski (2016), Urban (2008), Alcock (2000) and Onnisamaa et al. (2015), must be accompanied by consideration of several important elements: time outside of direct work with children dedicated to collective professional development;

7 „To learn how to document is to learn how to create a space and time to step back, to see, to listen, to allow the children to do and to allow oneself to discover them - it is to experience the ethical stance of suspension. In this subtle intentional suspension, the educator sees children's signals and listen to their voices (notices), realizes what she saw and listened to (becomes aware) and her wonderment drives her to record it (records)." (Oliveria-Formosinho \& de Sousa 2019, p. 43) 
pedagogical coordination ${ }^{8}$ (or guidance) in the process of critical and reflective process of pedagogical documentation to meet the need of practitioners to feel safe in an environment filled with insecurity and unpredictability; and initial education and lifelong learning to create a support network in agreement around basic pedagogical foundations for creating a competent system (Urban et al., 2012). Rintakorpi (2016) states that the practice in which the curriculum is realized contains the beliefs of that society about childhood, child, learning, future, good life, but also creates its own social context, or "institutional reality in which social activity forms social objects-documents." (Rintakorpi, 2016, p. 4). Thus, the definition of pedagogical documentation entails the need for a comprehensive understanding of practice and theory, as well as understanding the position and meaning of the individual and the position and meaning of the collective and the system. The translation of pedagogical documentation interpreted in this way into the legislative framework is certainly very demanding and implies an interdisciplinary approach. This paper at this point will only present the pedagogical perspective of the currently existing legislative framework.

It is extremely important that the legislative framework is consistent with pedagogical theoretical frameworks in order to minimize in practice all possible doubts and ambiguities related to the binding and prescribed operation of a very complex system of institutional early and preschool education and enable appropriate curriculum development and quality assurance. The question of synchronization of these two frameworks is the main problem of this paper, so the aim is to present the content of several legal regulations that directly govern the system of early and preschool education and put them in relation to contemporary theory in determining pedagogical documentation. The purpose of this paper is by achieving the stated goal provide theoretical and empirical support for the creation of a legislative framework in line with contemporary pedagogical theory and practice of early and preschool education.

\section{METHODOLOGY}

The content of the following documents was presented:

- National Curriculum for Early and Preschool Education (Official Gazette, No. 5/15),

- Act on Preschool Education (Official Gazette, No. 10/97, 107/07, 94/13, 98/19),

- State Pedagogical Standard for Preschool Education (Official Gazette, No. 63/08) and

8 „Investing in a system of pedagogical coordination is in line with the need of focusing not just on the individual competences of practitioners, but on creating competent system." (Sharmahd \& Peeters, 2019, pp. 62-63) 
- Ordinance of the content and forms of pedagogical documentation and records on children in kindergartens (Official Gazette 83/01).

These documents were chosen for presentation because they form the basic legislative framework within which the obligation and manner of keeping pedagogical documentation are invoked. The content was analyzed by using a descriptive content analysis which Cohen et.al. (2007) thought to be a valid method for analyzing educational documents. The paper presents the content related to pedagogical documentation within the document of the National Curriculum, which due to its foundation in modern theory and practice served as a starting point for the presentation of the content of other regulations. The content was thoroughly read and codes were created in line with the main aim of this paper. For the purpose of analyzing the content of legal regulations, in addition to identifying the main code (the key word) documentation, the codes were also appointed by identifying the meaning relating to the purpose of documentation listed in the National Curriculum (2015) - assessment of children's achievements and competencies, curriculum design and partnership with parents and communication with the social community. This formed the code frame within which the content of the mentioned documents was displayed. This required a thorough re-reading of the documents and, by identifying key words or phrases (documentation), placing the content into proposed code frame. When identifying the content that relates to the purpose of documentation listed in the National Curriculum (2015), it required a clear understanding of the pedagogical documentation as explained earlier in the paper since the documents often hold a meaning that is implicit and not detectable through single word or phrase analysis.

\section{RESULTS AND DISCUSSION}

The National Curriculum (2015) came into force with the pedagogical year 2015/2016. During the past 6 pedagogical years, the National Curriculum (2015) should have become the basis of educational work with children of early and preschool age in the Republic of Croatia. The document is comprised of 7 chapters in which it systematically refers both directly and implicitly to pedagogical documentation. Pedagogical documentation is explained in detail in Chapter 5, which describes the relationship between the national curriculum and the kindergarten curriculum. It should be noted that the National Curriculum (2015) sets out the basic principles that ensure compliance throughout the system: flexibility of the educational process in kindergarten, partnership of kindergartens with parents and the community, ensuring educational continuity and openness to continuous learning and readiness to improve practice. The principles have been clarified in sufficient detail to make their interpretation in different contexts as consistent as possible. Likewise, the National 
Curriculum (2015) states and explains the fundamental values that guide educational activities: knowledge, identity, autonomy, responsibility, creativity, and humanism and tolerance. At its core, the National Curriculum (2015) is based on the goal of ensuring the welfare of the child, his or her overall development, upbringing and learning, and the development of competencies. Competencies are explained in sufficient detail in the text, while emphasizing their development, integrity and contextual and individual dependence. In Chapter 5, the National Curriculum (2015) directly mentions pedagogical documentation in the part related to the planning and design of kindergarten curricula. The National Curriculum (2015) states the following: "In curriculum planning, it is especially important to carefully monitor, observe and understand children, as well as to document their activities. Documenting and jointly interpreting children's activities is the basis for preparing the environment, appropriate educational interventions of educators and harmonizing their overall educational work with individual differences of children (different interests, opportunities, needs, prior knowledge, learning styles)" (National Curriculum, 2015, p. 44). The National Curriculum (2015) very precisely defines pedagogical documentation as a research process: "Documentation implies the systematic collection of documentation (ethnographic records), which enables observation and better understanding of the child's actions, and thus providing better support for his development. It contributes to creating a culture of inclusion and dialogue between all participants in the kindergarten. (...) Documentation is in itself a research process that develops in parallel with the development of factors that undertake documentation, so its purposes and forms are stated only in outline" (National Curriculum, 2015, p. 45). Further in the document, pedagogical documentation is explained through three areas of purpose - assessment of children's achievements and competencies, curriculum design and partnership with parents and communication with the social community. Numerous forms of documentation focused on the activities of children and the activities of preschool teachers are also outlined.

In relation to the threefold purpose of pedagogical documentation, according to the National Curriculum (2015), pedagogical documentation does not serve as a tool for assessing children's abilities, but as an insight into the child's learning process. Pedagogical documentation will provide children with concrete and visible memories of their own action (Forman \& Fyfe, 1998), which is important due to our understanding that the child has metacognitive abilities (Bruner, 2000) and is able to think about their own learning process (Slunjski, 2020). Slunjski (2020) states that pedagogical documentation, which mainly draws its foundation from the Reggio Emilia approach, actually relies on formative assessment based not on the need to normalize the child's development, but on the need for transformative change and the development of the discourse of meaning making. Documentation also serves to shape the curriculum in such 
a way that through documentation the preschool teacher actively explores his or her practice as well as the learning process of each individual child and their interaction as a group (as referred to as group learning by Krechevsky et al., 2013). Pedagogical documentation will provide practitioners with an additional understanding of children's learning processes and allow for more accurate preparation for the next steps in that process (Rintakorpi, 2016). It is thus evident that the curriculum essentially derives from the child, and the preschool teacher is in the function of supporting the learning process. The documentation provides the preschool teachers an insight into the 'invisible reality' of the educational process, which includes his image of the child, implicit pedagogy and personal principles and values that are an integral part of the educational process. Insight into this 'invisible reality' creates opportunities for the preschool teachers to develop and realize the flexibility of their own practice. Therefore, according to the National Curriculum (2015), pedagogical documentation is a tool that enables active research and development of educational reality (for educators, children, parents and community members) and co-construction of the curriculum including all the specifics of each educational institution and group. It cannot be planned outside the educational reality, but arises directly from the child. By linking it to the principle of ensuring the kindergarten's partnership with parents and the community, the documentation needs to be made accessible and transparent. Pedagogical documentation will provide other participants in the process (parents, the wider community) with information about what is happening in the institution of early and preschool education (Somolanji Tokić \& Vukašinović, 2018), which is also a way to respect their reactions and support and respect the context in which direct and indirect learning occurs (Somolanji Tokić \& Vukašinović, 2020). The documentation enables the visibility of early and preschool education, so the community can respond to the needs, but also the initiatives of the child of early and preschool age. In this way, both parents and members of the community to which the child belongs participate in the co-construction of the curriculum.

\section{THE ACT ON PRESCHOOL EDUCATION (Official Gazette, No. 10/97, 107/07, 94/13, 98/19)}

The Act on Preschool Education is a text that retains its basic form from 1997 with amendments from 2007, significant amendments for this topic from 2013 and less significant amendments for this topic from 2019. Article 1a, paragraph 1, determines how the kindergarten performs the tasks of enrollment and discharge of children from the kindergarten, with the taking care of appropriate documentation and the issuing of certificates and opinions. Article 15 , paragraph 1 stipulates that the upbringing and education of children of early 
and pre-school age is carried out on the basis of the national curriculum for preschool upbringing and education and the kindergarten curriculum. The national curriculum was adopted in 2015 , thus satisfying the presumption of the Act (2019) on the positioning of the national curriculum as a basis for the realization of educational work in the system of early and preschool education. Article 15 , paragraph 4 determines how the kindergarten curricula determines the program, the purpose of the program, the holders of the program, the manner of realization of the program, the timing of the activities of the program and the manner of evaluation. Furthermore, Article 19, paragraph 2 of the Act (2019) stipulates that the organization and implementation of educational work is also carried out on the basis of the State Pedagogical Standard (2008) referred to in Article 6 of the Act (Article 6 prescribes the State Pedagogical Standard of Preschool Education which determinates the structural conditions for operation of kindergartens). Article 21, paragraph 1 stipulates that the kindergarten performs its activity on the basis of the annual plan and program adopted for each pedagogical year.

In relation to the set methodological framework, the Act (2019) defines the powers of kindergartens and, among other things, prescribes the obligation to keep appropriate documentation (Article 1.a). The documentation in the context of the obligations of the kindergarten is given in more detail:

\section{"Article 52}

(1) The kindergarten keeps pedagogical and health documentation and records on children.

(2) Forms of pedagogical documentation and records shall be prescribed by the Minister of Education and Sports.

(3) Forms of health documentation and records shall be prescribed by the Minister of Health.

(4) The funds for keeping the documentation referred to in paragraph 1 of this Article shall be provided by the founder of the kindergarten. "

It also prescribes misdemeanor provisions if the kindergarten does not keep the documentation and records prescribed by the Act (Article 52. b, para. 1). The same article and paragraph state the obligation to comply with the State Pedagogical Standard (2008), the adoption of the kindergarten curriculum and the annual plan and program of the kindergarten in accordance with the provisions of the said Act (2019).

In the context of the principles on which the National Curriculum (2015) is based and which are implemented in the threefold purpose of documentation, certain strongholds for the insurance of the flexibility of the educational process, and the nurture of the partnership with parents and the community can be read from the Act (2019) (Article 16, paragraph 1 sets out the obligations 
of the kindergarten to ensure appropriate conditions for the growth and development of each child and to establish cooperation with the parents and the family; Article 3, paragraph 2 stipulates that pre-school education is carried out in accordance with the developmental characteristics and needs of children and the social, cultural, religious and other needs of the family) and openness to continuous learning and readiness to improve practice (Article 39 establishes the educational council as a professional body of the kindergarten which, according to paragraph 3, deals with professional issues of educational work). These strongholds, although not directly related to pedagogical documentation, are an important detail stated in the Act (2019) which potentially ensures compliance and the obligation to conduct educational work according to the modern national curriculum and kindergarten curriculum which positions pedagogical documentation as the basic tool of practitioners. It also provides insight into the educational process to the child's parents and the community, as well as to the children and preschool teachers themselves for the purpose of co-constructing the curriculum and developing the educational reality. However, these strongholds need to be clearly articulated and appropriately positioned in the Act (2019) in order to emphasize their importance and the imperative of their observance and execution.

\section{STATE PEDAGOGICAL STANDARD OF PRESCHOOL EDUCATION (Official Gazette, No. 63/08)}

The state pedagogical standard referred to in the Act (2019) has been in force since 2008. The main purpose of the State Pedagogical Standard is:

\section{"Article 2}

(1) This Standard determines the conditions for the work of kindergartens and other legal entities that perform the activity of an organized form of educational work with preschool children. ".

Referring to pedagogical documentation, the State Pedagogical Standard states the following:

"Article 26

(2) A preschool teacher is a professionally qualified person who implements an educational program of work with preschool children and professionally considers the educational process in his or her educational group. He timely plans, programs and evaluates educational work in the agreed periods. Collects, makes and maintains supplies for working with children and takes care of the aesthetic and functional arrangement of the space for performing various activities. Works to meet the everyday needs of children and their developmental tasks and encourages the development of each child according to his 
abilities. Keeps documentation on children and work and meets professional requirements in the organization and improvement of the educational process. Cooperates with parents, experts and the professional team in the kindergarten as well as with other participants in the upbringing and education of preschool children in the local community. He is responsible for the implementation of the program of work with children as well as for the equipment and teaching aids used in the work. ".

From Article 26, paragraph 2, it can be read in principle that the State Pedagogical Standard (2008) recognizes documentation as an essential part of the educational process. The documentation is included in Article 26 as an indispensable part of early and preschool education and can be read as integrated into other obligations of preschool teachers, which are essentially aimed at improving the educational process. However, what can also be read is the planning, programming and evaluation of the work of preschool teachers according to agreed periods as well as development tasks. Article 2 of the State Pedagogical Standard (2008) determines the meaning of the term program by stating the following:

\section{"Article 2}

(2) For the purposes of this Standard, certain terms have the following meanings:

5. Program - an act prescribing the general goals and contents, material conditions and holders of educational work according to the Program Orientation of Preschool Education of Preschool Children. “.

This needs to be emphasized primarily because of the reference to the 1991 Program Orientation for the Education of Preschool Children (1991), which was in force until 2013, or until the entry into force of the National Curriculum (2015). It clearly states that there has been no synchronization of the State Pedagogical Standard (2008) with the change of the Act (2019) and the National Curriculum (2015), which further contributes to the misunderstanding present in the entire system of early and preschool education. Furthermore, it is noticed that the State Pedagogical Standard (2008) defines the program through the realization of content, which is not in line with the National Curriculum (2015) which declares itself as progressive, open, integrated and encourages co-construction of educational process without predefined content or schoolification of early and preschool education. Given that the State Pedagogical Standard (2008) lists the learning content as part of the programs implemented in kindergarten, it can be concluded that this document is based on outdated paradigms about the child, the childhood and the learning process that are not in cohesion with the modern approach as represented in the National Curriculum (2015). From this arises the basic preoccupation of the authors of this paper, or a different interpretation of the basic concepts of pedagogical documentation 
in practice, which partly arises from different starting points in the legislative framework.

Article 17 of the State Pedagogical Standard (2008) states that the kindergarten provides, inter alia, a plan of educational work for the implementation of the preschool program and Article 20 states that "Equipment and organization of space must be appropriate to the child's age and guarantee the implementation of certain developmental tasks required by programs.". An insight into the National Curriculum (2015) reveals that the preschool curriculum does not recognize developmental tasks at all, and does not recognize predetermined and normatively determined outcomes. It does sets very broadly defined expectations through basic competencies. Thus, the planning and evaluation of educational work assumed by Article 26 of the State Pedagogical Standard (2008) in relation to the National Curriculum (2015) (assessment of children's achievements and competencies, curriculum design) becomes questionable.

Article 29, paragraph 2 of the State Pedagogical Standard (2008) states that in addition to direct work with children in a group, the preschool teacher should spend the rest of the time up to full hours in planning, programming and evaluating work, preparing space and incentives, cooperating with and counseling parents as well as working on their professional development. It is based on Article 25 , paragraph 2, which states that preschool teachers, professional associates and principals are obliged to provide continuing professional development in accordance with the plan and program adopted by the Minister responsible for education. Furthermore, Article 30 lists professional associates in kindergarten and gives descriptions of their work, which shows that professional associates are positioned as equal, and not hierarchically placed employees in relation to preschool teachers. Through collaborative relationships with preschool teachers, professional associates are focused on improving the entire educational process. It is interesting to mention Article 32, paragraph 1, which states that professional associates are also obliged to spend 25 working hours per week in direct work with children, preschool teachers and parents. From the mentioned articles, although pedagogical documentation is not explicitly mentioned, one can again see strongholds for fostering openness for continuous learning and readiness to improve the practice assumed by the National Curriculum (2015) and strongholds for developing a network of support and lifelong learning that indirectly leads to understanding the purpose of pedagogical documentation. Because "Curriculum planning is based on quality communication and professional cooperation of preschool teachers, as well as other professional employees of the kindergarten. It includes joint reflection, implementation and evaluation of the educational process, reflecting the belief that quality educational practice is a collective rather than an individual achievement." (National Curriculum, 2015, p. 44). 


\section{ORDINANCE OF FORMS AND CONTENT OF PEDAGOGICAL DOCUMENTATION AND RECORDS ON CHILDREN IN KINDERGARTEN (2001)}

The article 52, paragraphs 1 of the Act (2019) states that every kindergarten must keep pedagogical record of children. The content and forms of keeping pedagogical documentation are regulated by the Ordinance of forms and content of pedagogical documentation and records on children in kindergarten (2001).

Article 2 of the Ordinance (2001) under the pedagogical documentation and records on children states the following:

- Children's registry,

- Book of pedagogical documentation of children of the educational group,

- Address book of children,

- Yearbook of the kindergarten,

- Annual plan and program of educational work,

- Annual report on the implementation of the work plan and program,

- Professional development program,

- Dossier of a child with special needs and

- Minutes book.

When stating pedagogical documentation and record on children in the Article 2 of the Ordinance (2001), it is not indicated what the pedagogical documentation is and what the children's records are. Each document is simplified separately in further articles. For the purposes of this paper, the Book of pedagogical documentation of children of the educational group is singled out, which is explained in more detail in Article 4 by stating its content: orientation plan and program of educational work and its evaluation (usually quarterly), weekly plan and program of educational work, diary of the educational work and joint activities of children and adults. In contrast to this strict planning of activities and the content of learning itself, the National Curriculum (2015) requires the planning of the educational process based on documented, perceived interest and opportunities of children. The evaluation of the educational process according to the National Curriculum (2015) is assisted by pedagogical documentation in the context of interpreted photographs, notes, videos and other ethnographic records that provide insight into the way the child develops and learns, and not just the outcome of that learning. In addition, the pedagogical documentation listed in the National Curriculum (2015) provides insight into the ways in which the preschool teacher supports these learning processes and understands them. Insight into the layout of the Book of pedagogical documentation of children of the educational group, which is presented at the end of 
the Ordinance (2001), shows a strong aberration from the contemporary understanding approach assumed by the National Curriculum (Figure 1).

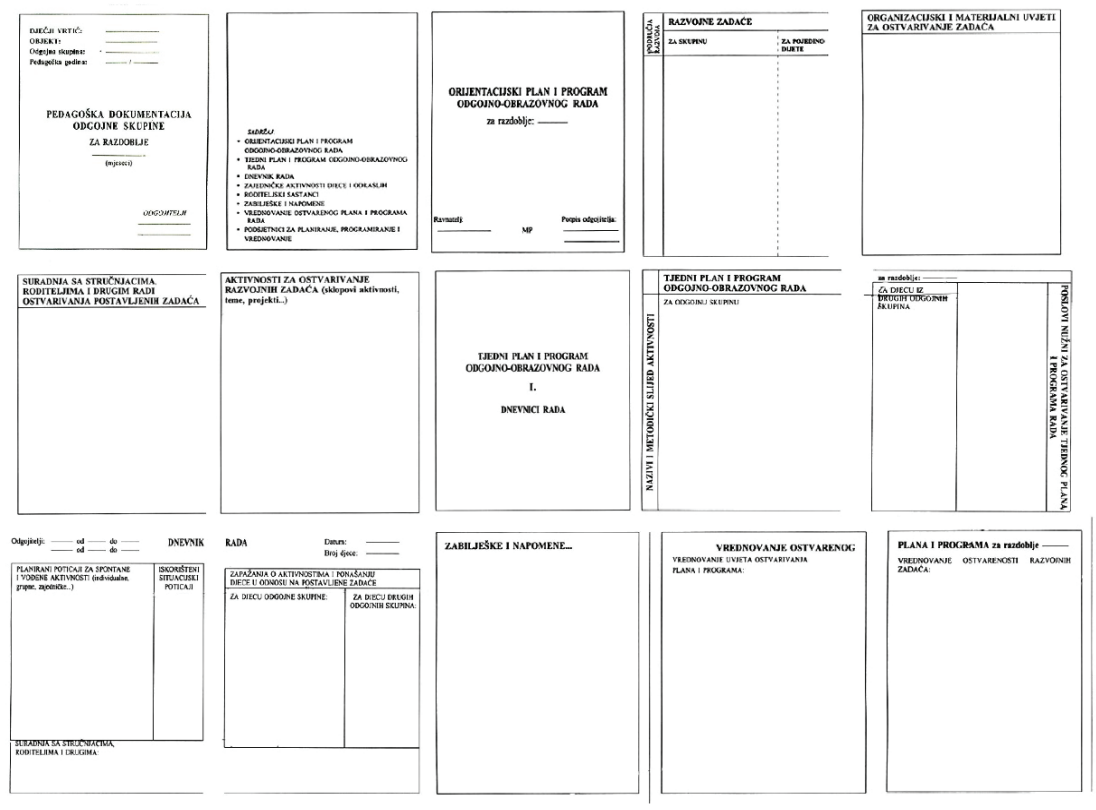

Figure 1 Appearance of the Book of pedagogical documentation of children of the educational group (Retrieved from the Ordinance, 2001)

The Book of Pedagogical Documentation shows how preschool teachers are expected to divide the child's development into development areas and plan activities for those development areas. The National curriculum (2015) defines child development as holistic and inseparable into fragmented areas. Also, the National Curriculum (2015) encourages the development of all children's competencies that need to be encouraged and observed in the context of the capabilities of each individual child regardless of his or her chronological age. Competences are understood as a developmental category and cannot be observed or assessed one-time and in isolation from the context. The Book of pedagogical documentation, on the contrary, very clearly seeks a division according to developmental areas, which unjustifiably parcels out the child's naturally integrated development. This paper does not want to point out that it is not possible to identify certain developmental areas in a child's development. However, from a theoretically contemporary point of view, it is unjustified to use developmental areas as a backbone of planning educational work in early and preschool education institutions. The areas of development and development tasks listed in the Ordinance (2001), and contained in the Book of Pedagogical Documentation, indicate a scholastic approach to education with prescribing 
separate methodical subject areas, which together can easily lead preschool teachers to plan the educational process by fragmenting children's development. Pedagogical documentation that is in line with contemporary pedagogical theory and proscribed by the National Curriculum (2015) can be recognized only in one part of the Book of Pedagogical Documentation related to the Work Diary where the preschool teacher has the autonomy to record and interpret children's action. However, the question is to what extent the Diary is used in this form, given that the Book of Pedagogical Documentation assumes that the child's abilities should be measured at certain time intervals (weekly, quarterly) and plan content that helps achieve predetermined developmental tasks.

From the above, it can be observed that the Ordinance (2001) and the National Curriculum (2015) do not have consistent images of the child and the child's development. According to Antulić Majcen and Pribela-Hodap (2017), the recognition of the child and his development as a "humane, complete, active, social and individual being" (Antulić Majcen \& Pribela-Hodap, 2017, p. 21 ) is a turning point in preschool education in Croatia positioned first within the Program Orientation for the Education of Preschool Children (1991) and further strengthened by the National Curriculum (2015): "In creating a spatial-material learning environment, the emphasis is on accepting the nature of the child's learning that is integrated and holistic, so different educational activities are not divided into subject areas or subject methods" (National Curriculum, 2015 , p. 38). It is possible to assume that the potential misunderstanding of pedagogical documentation observed in practice (Slunjski, 2015;2018) partly stems from these forms of the Book of Pedagogical Documentation that manage educational practice according to the principle of creating a ready-made methodic instruction.

Pedagogical documentation in the National Curriculum (2015) is set as a prerequisite for the realization of all contemporary features of early and preschool education. The value of documentation as a tool for achieving a humanistic, integrated, open and progressive curriculum is infused throughout the National Curriculum (2015). Many authors such as Katz (1998), Dahlberg et al. (1999), Alcock (2000), Slunjski (2020), Rintakorpi (2016) and Sharmahd and Peeters (2019) emphasize the importance of pedagogical documentation and encourage practitioners to recognize its value. However, inconsistencies in the regulations governing and monitoring early and preschool education can mislead practitioners and result in confusion on the very meaning of the term pedagogical documentation, its purpose and importance, and the obligation to comply with it. A review of the National Curriculum (2015), the Act (2019), the Ordinance (2001) and the State Pedagogical Standard (2008) reveals different levels of understanding and interpretation of these terms as well as different paradigms about the child and childhood that underlie these documents. 
Reading the National Curriculum (2015) prescribed by the Act (2019), it is noticed that this document emphasizes that the child's development is holistic and integrated, and the developmental and contextual features of the educational process are prioritized as follows: "Curriculum design plans what children can learn, not what they should do. This means that the emphasis is placed on shaping the conditions for children's learning and situations that are conducive to certain learning activities, and not the activities themselves, or their precise course" (National Curriculum, 2015, p. 43). The National Curriculum (2015) explains documentation as a tool for implementing all prescribed principles and values. By documenting and interpreting the educational process, the asymmetry of the roles of adults and children in the educational process is reduced, ensuring the realization of democratic values. A review of the Act (2019) shows that pedagogical documentation is only mentioned through the obligations of the kindergarten (Articles 1 and 52), from which it is not possible to create a deeper understanding. In this sense, the Act (2019) may seem imprecise. However, it is necessary to allow the possibility of its supplementation and clarification of educational process with children of early and preschool age, as well as its implementation in practice, with the National Curriculum (2015), which clarifies the basic starting points and goals in this regard.

For this reason, it is necessary to emphasize the need for a clear positioning and monitoring of the national curriculum and kindergarten curriculum in the Act (2019), given that in addition to the curriculum there are other documents whose purpose and content are not sufficiently clarified or specified in the Act. One of such documents is the State Pedagogical Standard (2008), which refers to the Program Orientation for the Education of Preschool Children (1991) as a precursor to the National Curriculum (2015). The State Pedagogical Standard (2008), which is not corresponding to the basic curriculum, creates space for various arbitrary interpretations about which document or regulation should the binding one. Furthermore, calling through the State Pedagogical Standard (2008) to achieve the content of teaching is in direct conflict with the contemporary understanding of early and preschool curriculum and the development and learning of children of early and preschool age, and such non-contemporary way of thinking actually conditions admission to pedagogical documentation as an administrative procedure. It is additionally inappropriately strengthened by the Ordinance of forms and content of pedagogical documentation and records on children in kindergarten (2001), which is prescribed by Act (2019). It explains in detail the appearance and content of the Book of pedagogical documentation of children of the educational group, which fully fragments the child's development according to artificially created subject areas, developmental tasks and a predetermined time frame. This form of pedagogical documentation should have been the first in line for renewal and synchronization after the entry into force of the National Curriculum in 2015, however, in its current form it 
still persists and systematically obstructs possible changes and development of educational practice. Namely, it is still a formal form of keeping pedagogical documentation that is required of preschool teachers. Such approval of formalities certainly has its origin in a very narrow and grammatical understanding of the Ordinance (2001). The National Curriculum (2015), on the opposite, due to its scope and extensiveness, must be interpreted teleologically, and as such, and due to the nature of the process it regulates, it should completely derogate the Ordinance (2001) and its content. Thus, the so-called 'alternative' forms of pedagogical documentation and their purpose, which preschool teachers often talk about when referring to the National Curriculum (2015), should finally be understood as primary forms and purpose independent of the will of the individual or of outdated regulations. However, understanding the form and purpose of modern pedagogical documentation largely depends on the professional identity of preschool teachers (Sharmahd \& Peeters, 2019; Slunjski, 2020; Urban, 2012) whose development is intertwined with the process of documentation, which is a significant challenge when it comes to attempt to systematically implement change. Alcock (2000), Alasuutari and Karila (2010) as well as Slunjski (2020) point out that defining basic concepts does not promise understanding and applying them in practice, nor does agreeing on defining basic concepts through legislative and pedagogical theoretical framework and pedagogical practice guarantee their understanding and application in practice. Nevertheless, it provides a complementary approach to the problem from which it is possible to move forward with quality changes. Reflection, observation and interpretation of one's own and others' documentation, Alcock (2000) points out, results in greater engagement of educators and systematic "deconstruction and reconstruction of one's own practice" (p. 19). It has implications primarily for the child and then for the parents and the community. It is necessary to ensure the conditions for such a practice to be implemented from within (Slunjski, 2016; Urban, 2008), and that means renewing such a legislative framework that will not interfere with such a practice as it does today. This requires a legislative framework that is in line with modern pedagogical theory and practice.

\section{CONCLUSION}

Contemporary pedagogical knowledge, if it can be called contemporary at all given that they have been present in the pedagogical literature for more than 30 years, rejects the globalization of childhood and encourages the co-construction of the educational process in accordance with the contextual and cultural characteristics of each institution. Also, dissociation from the exclusively structural determinants of education and the evaluation of learning and abilities of children is strongly encouraged. An emphasis is placed on the advantages of developing process determinants of education. As a means for achieving 
all of the above, contemporary pedagogy states pedagogical documenting as a main tool in order to understand the learning process of children, to reinforce relationship with parents and the community, to gain insight into the preschool teachers own practices, to gain insight into the 'invisible reality' of education, and to position curriculum as a platform of co-construction. However, literature also shows (Mitchell, 2020; Moss, 2008; Rintakorpi, 2016; Robert-Holmes, 2016; Urban, 2010; Vandenbroeck, 2020) that even though pedagogical theory by using pedagogical documentation seeks and encourages multiple discourses and a democratic debate, politicians and policy makers responsible for one aspect of a competent system continuously strive to achieve and maintain the status quo. As Vandenbroeck states, "They make their own truth and "they suffer an absence of doubt"." (Vandenbroeck, 2020, p. 20). The process of schoolification is a visible act of maintaining 'an absence of doubt' by reducing early and preschool education to the narrow process of readying children for school (summative assessment, prescribed content, predetermined goal oriented curriculum). As Somolanji Tokić and Borovac (2020) noted, "preschool practice digresses into the schoolification of the ECEC system where there is less room for error when the assessment time comes" (Somolanji Tokić \& Borovac, 2020, p. 238) and the legislative framework does not encourage preschool teachers to do anything differently.

The National Curriculum (2015) as a core document of early and preschool education in the Republic of Croatia which defines the goals, principles and values of education of children of early and preschool age emphasizes pedagogical documentation as an indispensable part of the educational process. Pedagogical documentation is understood as a multidimensional process and as a basic tool for the development of contemporary early and preschool curriculum, and the National Curriculum (2015) as an open and progressive document that respects and positions pedagogical documentation based on pedagogical theory and practice. Still, an insight into other regulations that make up the legislative framework governing educational reality, revealed a significant deviation in terms of pedagogical documentation. More worrying is the positioning of the national curriculum and the kindergarten curriculum in relation to other regulations that also govern the educational practice itself. Thus, for example, the Act (2019) insufficiently positions the national curriculum as well as the kindergarten curriculum as the core of the educational process, while referring to documents that are in a substantive conflict with the National Curriculum (2015). The Act (2019) also refers to regulations that are no longer in force and regulations that directly reinforce the process of schoolification.

Considering that it has been clear for years that the current regulations have not resolved the issues of content that are problematized in this paper (which also contribute to legal uncertainty) there is an evident need for an interdisciplinary approach that will translate contemporary pedagogical theory and practice 
in an appropriate way into a legislative framework. The system of early and preschool education has been on the margins of the education system for too many years, as evidenced by this unregulated and uncoordinated legislative framework that goes from one pedagogical extreme to another. It is clear that there is disagreement not only on pedagogical documentation, but also on other elements (for example, the purpose of the annual plan and program in addition to the kindergarten curriculum is certainly interesting and worth critically analyzing in the existing Act, as well as ways and forms of professional development, requirements for advancement etc.) and in order to create a system that works in the direction of progress, in the direction of a competent system, it is necessary to start to create the solution to these obstacles, which unfortunately act too disruptively on the very quality of the educational system. The coordination of these frameworks is only one of the much-needed changes in the system of early and preschool education in the Republic of Croatia.

This paper sought to define pedagogical documentation in the light of the contemporary paradigm of early and preschool education and provide insight into the content of current acts, standards and regulations regarding the definition of pedagogical documentation with the full awareness that selected current regulations are not the only ones whose content should be read and updated. The modern educational approach in early and preschool education is based on the co-construction of knowledge and the entire educational process in which all participants are equally important and it does not have its final form but is constantly evolving and improving. As Vandenbroeck (2020) says, "we do not wish education to become a matter of technocratic training. Pedagogy probably requires the opposite of scientific fragmentation. It requires to look at relations between fields from a holistic point of view. But, above all, it requires ideology, meaning the debate on a possible horizon, on what constitutes the good life and thus the repoliticisation of (early childhood) education." (Vandenbroeck, 2020 , p. 23). For this reason, it is important to have an organized system and a legislative framework that has its origins in modern pedagogical scientific facts and theoretical foundations and modern pedagogical practice in order to avoid the trap of one-sided prescribing and top-down changes (Urban, 2008) and in order to adequately support the development of the competent system (Urban et al., 2012).

\section{REFERENCES}

1. Alasuutari, M., \& Karila, K. (2010). Framing the picture of the child. Children \& Society, 24(2), 100-111.

2. Alcock, S. (2000). Pedagogical Documentation: Beyond observations. Institute for Early Childhood Studies. http://researcharchive.vuw.ac.nz/handle/10063/882 
3. Antulić Majcen, S., \& Pribela-Hodap, S. (2017). Prvi koraci na putu prema kvaliteti: Samovrednovanje ustanova ranog i predškolskog odgoja i obrazovanja. Nacionalni centar za vanjsko vrednovanje.

4. Bruner, J. (2000). Kultura obrazovanja. Educa.

5. Carr, M., \& Lee, W. (2019). Learning Stories: Pedagogic Practice and Provocations. In J. Formosinho \& J. Peeters (Eds.), Understanding pedagogic documentation in early childhood education: revealing and reflecting on high quality learning and teaching (pp. 4-31). Routledge.

6. Cohen, L., Manion, L., \& Morrison, K. (2007). Metode istraživanja u obrazovanju. Naklada Slap.

7. Dahlberg, G., Moss, P., \& Pence, A. (1999). Beyond quality in early childhood education and care: Postmodern perspectives. Falmer Press.

8. Državni pedagoški standard predškolskog odgoja i naobrazbe. Narodne novine, br. 63/08. https://narodne-novine.nn.hr/clanci/sluzbeni/2008_06_63_2128.html

9. Forman, G., \& Fyfe, B. (1998). Negotiated Learning Through Design, Documentation, and Discourse. In C. Edwards, L. Gandini \& G. Forman (Eds.), The hundred languages of children: The Reggio Emilia approach - Advanced reflections (pp. 239-260). Ablex.

10. Forman G., Hall, E., \& Berglund, K. (2001). The power of ordinary moments, Child Care Information Exchange, 141, 52-53.

11. Gunningham, N., \& Sinclare, D. (2017). Smart regulation. In Drahos, P. (Ed.), Regulatory theory: Foundations and applications (pp. 133-148). ANU Press, The Australian National University.

12. Katz, L. G. (1998). What can we learn from Reggio Emilia. In C. Edwards, L. Gandini \& G. Forman (Eds.), The hundred languages of children: The Reggio Emilia approach - Advanced reflections (pp. 27-45). Ablex.

13. Krechevsky, M., Mardell, B., Rivard, M., \& Wilson, D. G. (2013). Visible Learners: Promoting Reggio-Inspired Approaches in All Schools. Jossey-Bass.

14. Lenz Taguchi, H. (2010). Going Beyond the Theory/Practice Divide in Early Childhood Education: Introducing an intra-active pedagogy. Routledge.

15. Mitchell, L. (2020). Transforming early childhood education: dreams and hope in Aotearoa New Zealand. In M. Vandenbroeck (Ed.), Revisiting Paulo Freire's Pedagogy of the Oppressed: Issues and Challenges in Early Childhood Education (pp. 195-219). Routledge.

16. Moss, P. (2012). Readiness, Partnership, a Meeting Place? Some Thoughts on the Possible Relationship between Early Childhood and Compulsory School Education. FORUM, 54 (3), 355-368.

17. Moss, P. (2013). The Relationship between Early Childhood and Compulsory Education: A Properly Political Question. In P. Moss (Ed.), Early Childhood and Compulsory Education: Reconceptualising the Relationship (pp. 2-49). Routledge. 
18. Moss, P., \& Dahlberg, G. (2008). Beyond quality in early childhood education and care: Languages of evaluation. New Zealand Journal of Teachers' Work, 5(1), $3-12$.

19. Nacionalni kurikulum za rani i predškolski odgoj i obrazovanje. Narodne novine, No. 5/15. https://narodne-novine.nn.hr/clanci/sluzbeni/2015_01_5_95.html

20. Nacrt Prijedloga Zakona o izmjenama i dopunama Zakona o predškolskom odgoju i obrazovanju (2019). Ministarstvo znanosti i obrazovanja. https://mzo.gov.hr/ UserDocsImages/dokumenti/PristupInformacijama/Zakoni $\% 20 \mathrm{u} \% 20$ proceduri/ Zakon\%20o\%20izmjenama\%20i\%20dopunama\%20Zakona\%20o\%20pred\%C5\%A1kolskom\%20odgoju\%20i\%20obrazovanju.pdf?fbclid=IwAR0Kou1JOBOu_0LV5gh7gi6LOmsNo3YpLfX4HHMM13pD_VY8WLrRYkn_3QA

21. Oliveria-Formosinho, J., \& de Sousa, J. (2019). Developing pedagogic documentation: Children and educators learning the narrative mode. In J. Formosinho \& J. Peeters (Eds.), Understanding pedagogic documentation in early childhood education: revealing and reflecting on high quality learning and teaching (pp. 32-51). Routledge.

22. Onnisamaa, E-L., Tahkokallio, L., \& Kalliala, M. (2015). From university to working life: an analysis of field-based studies in early childhood teacher education and recently graduated kindergarten teachers' transition to work. Early Years: An International Research Journal, 35(2), 197-210. https://doi.org/10.1080/0957514 6.2015.1011065

23. Pravilnik o sadržaju i obrascima pedagoške dokumentacije i evidencije o djeci u dječjim vrtićima. Narodne novine, No. 83/01. https://narodne-novine.nn.hr/clanci/ sluzbeni/2001_09_83_1422.html

24. Programsko usmjerenje odgoja i obrazovanja predškolske djece. Glasnik Ministarstva kulture i prosvjete RH, No. 7-8/91.

25. Rinaldi, C. (2006). In dialogue with Reggio Emilia: Listening, researching and learning. Routledge.

26. Rintakorpi, K. (2016). Documenting with early childhood education teachers: pedagogical documentation as a tool for developing early childhood pedagogy and practices. Early Years, 36(4), 399-412. https://doi.org/10.1080/09575146.2016.1 145628

27. Roberts-Holmes, G. P. (2014). The 'datafication' of early year's pedagogy: 'if the teaching is good, the data should be good and if there's bad teaching, there is bad data. Journal of Education Policy, 30(3), 302-415. http://dx.doi.org/10.1080/026 80939.2014.924561

28. Slunjski, E. (2015). Izvan okvira, kvalitativni iskoraci u shvaćanju i oblikovanju predškolskog kurikuluma. Element.

29. Slunjski, E. (2016). Izvan okvira 2 - Promjena, od kompetentnog pojedinca i ustanove do kompetentne zajednice učenja. Element.

30. Slunjski, E. (2018). Izvan okvira 3 - Vođenje: prema kulturi promjene. Element. 
31. Slunjski, E. (2020). Izvan okvira 5 - Pedagoška dokumentacija procesa učenja djece $i$ odraslih kao alat razvoja kurikuluma. Element.

32. Sharmahd, N., \& Peeters, J. (2019). Critical reflection, identity, interaction: Italian and Belgian experiences in building democracy through pedagogical documentation. In J. Formosinho \& J. Peeters (Eds.), Understanding pedagogic documentation in early childhood education: revealing and reflecting on high quality learning and teaching (pp. 52-66). Routledge.

33. Somolanji Tokić, I., \& Borovac, T. (2020). Children's symbolic play during the transition to school, International Journal of Early Years Education, 28(3), 232 245. DOI:10.1080/09669760.2020.1814210

34. Somolanji Tokić, I., \& Vukašinović, A. (2018). Virtualne društvene mreže i ostvarivanje partnerstva obitelji i dječjeg vrtića. Život i škola: časopis za teoriju i praksu odgoja i obrazovanja, 64(1), 105-116. https://doi.org/10.32903/zs.64.1.8

35. Somolanji Tokić, I., \& Vukašinović, A. (2020). Continuity of Educational Process Through Virtual Kindergarten During Covid-19 Outbreak - Case Study from Croatia. In L. Gómez Chova, A. López Martínez \& I. Candel Torres, (Eds.), EDULEARN20 Proceedings (pp. 7861-7870). IATED Academy. http://dx.doi. org/10.21125/edulearn.2020.1981

36. Urban, M. (2008). Dealing with uncertainty: challenges and possibilities for the early childhood profession. European Early Childhood Research Journal, 16(2), 135-152. http://dx.doi.org/10.1080/13502930802141584

37. Urban, M. (2012). Researching early childhood policy and practice. A critical ecology. European Journal of Education, 47(4), 494-507. https://doi.org/10.1111/ ejed. 12012

38. Urban, M., Vandenbroeck, M., Van Leare, K., Lazzari, A., \& Peeters, J. (2012). Competence Requirements in Early Childhood Education and Care - Final report. University of East London, University of Ghent.

39. Vandenbroeck, M. (2020). Facts matter. And so do ideologies. In M. Vandenbroeck (Ed.), Revisiting Paulo Freire's Pedagogy of the Oppressed: Issues and Challenges in Early Childhood Education (pp. 15-37). Routledge.

40. Vujičić, L. (2017). Razvoj znanstvene pismenosti u ustanovama ranog odgoja. Sveučilište u Rijeci, Učiteljski fakultet u Rijeci, Centar za istraživanje djetinjstva.

41. Wood, E., \& Hedges, H. (2016). Curriculum in early childhood education: critical questions about content, coherence, and control. The Curriculum Journal, 27(3), 387-405. https://doi.org/10.1080/09585176.2015.1129981

42. Zakon o predškolskom odgoju i obrazovanju. Narodne novine, No. 10/97, 107/07, 94/13, 98/19. https://www.zakon.hr/z/492/ Zakon-o-pred\%C5\%A1kolskom-odgoju-i-obrazovanju 